\title{
PENGEMBANGAN MODUL PEMBELAJARAN KIMIA BERBASIS POE (PREDICT, OBSERVE, EXPLAIN) PADA MATERI LARUTAN ELEKTROLIT DAN NON ELEKTROLIT
}

\author{
Etrie Jayanti \\ Universitas Islam Negeri Raden Fatah Palembang \\ Email: etriejayanti_uin@radenfatah.ac.id
}

\begin{abstract}
Abstrak: Penelitian ini merupakan R\&D (research and development) yang bertujuan untuk mengetahui validitas dan respon siswa terhadap modul pembelajaran kimia berbasis POE (predict, observe, explain) pada materi larutan elektrolit dan non elektrolit. Prosedur pengembangan dari penelitian ini mengadopsi model pengembangan produk Borg \& Gall. Penelitian ini melibatkan tiga validator yaitu validator ahli materi, validator ahli media/desain dan validator praktisi pendidikan/guru bidang studi. Subjek uji coba skala kecil dan uji coba skala menengah adalah siswa SMA N 3 Palembang. Instrumen pengumpulan data menggunakan lembar validasi, angket responden siswa dan pedoman wawancara. Hasil penelitian menunjukkan bahwa modul pembelajaran kimia berbasis POE (predict, observe, explain) pada materi larutan elektrolit dan non elektrolit memperoleh nilai persentase dari ahli materi sebesar 83,3\% dan dinyatakan dalam kategori valid, ahli desain/media memberikan penilaian dengan persentase sebesar 97,2\% dan dinyatakan dalam kategori sangat valid, praktisi pendidikan/guru bidang studi memberikan penilaian dengan persentase $88,8 \%$ dan dinyatakan dalam kategori sangat valid. Rata-rata persentase nilai dari tiga validator mencapai $89,9 \%$ dan dinyatakan pada kategori sangat valid. Respon siswa terhadap modul pembelajaran kimia berbasis POE (predict, observe, explain) pada materi larutan elektrolit dan non elektrolit dapat dikategorikan baik dimana pada uji skala kecil memperoleh persentase nilai sebesar 78,9\% dan dinyatakan dalam kategori baik, pada uji skala menengah memperoleh persentase nilai sebesar $82,0 \%$ dan dinyatakan dalam kategori baik.

Kata-kata kunci: modul, POE (predict, observe, explain), larutan elektrolit \& non elektrolit
\end{abstract}

\section{PENDAHULUAN}

Pembentukan kualitas sumber daya manusia bergantung pada salah satu bidang yang sangat penting yaitu pendidikan. Oleh karena itu peningkatan kualitas pendidikan harus selalu dilakukan. Salah satu upaya yang telah dilakukan oleh pemerintah yaitu dengan melakukan pembaharuan kurikulum. Kurikulum yang saat ini sedang diterapkan dan dikembangan oleh pemerintah adalah kurikulum 2013. Kurikulum 2013 merupakan upaya penyederhanaan kurikulum yang disiapkan untuk mencetak generasi dalam menghadapi tantangan massa depan. Dalam Paparan Wakil Menteri Pendidikan dan Kebudayaan Republik Indonesia Bidang Pendidikan (2014), proses pembelajaran pada kurikulum 2013 menggunakan pendekatan saintifik yang menyentuh tiga ranah, yaitu: sikap, pengetahuan, dan keterampilan. Dengan proses pembelajaran yang demikian maka diharapkan hasil belajar melahirkan siswa yang produktif, kreatif, inovatif, dan afektif melalui penguatan sikap, keterampilan, dan pengetahuan yang terintegrasi.

Namun pada kenyataannya, berdasarkan hasil wawancara guru dan observasi pada salah satu sekolah menengah atas di kota Palembang. Guru mengalami kendala dalam melaksanakan tuntutan kurikulum 2013 yang menuntut siswa harus lebih aktif di dalam kelas. Guru masih aktif sebagai pemberi informasi dan mendominasi pembelajaran di kelas, sedangkan siswa pasif sebagai penerima informasi, siswa cenderung hanya mendengarkan penjelasan materi dari guru, kemudian memperhatikan contoh penyelesaian soal yang diberikan, 
mencatat ulang ke dalam buku catatan lalu menyeselaikan soal yang ada di dalam buku teks. Buku dan proses kegiatan pembelajaran yang digunakan kurang menuntun siswa untuk aktif selama proses belajar, sehingga berdampak pada kurangnya pemahaman siswa terhadap materi yang diajarkan tersebut. Akibatnya siswa tidak dapat menguasai konsep-konsep materi kimia secara utuh dan siswa tidak dapat membangun konsep kimia tersebut secara fundamental. Salah satu konsep kimia yang penting namun masih sering dianggap sulit bagi siswa yaitu larutan elektrolit dan non elektrolit. Wulandaru (2015) menganalisis pemahaman konseptual materi larutan elektrolit dan non elektrolit. Kesulitan dalam memahami konsep larutan elektrolit dan nonelektrolit yakni 42,5\%. Hasil penelitian Medina (2015) menunjukkan bahwa persentase miskonsepsi yang dialami siswa setelah melaksanakan pembelajaran pada konsep larutan elektrolit dan nonelektrolit untuk persentase rata-rata miskonsepsi yang paling tinggi terdapat pada konsep senyawa ionik.

Salah satu cara yang cukup relevan untuk mengatasi masalah tersebut yaitu pengembangan bahan ajar yang efektif dan inovatif yang dikombinasikan dengan model pembelajaran agar dapat memudahkan guru dalam proses pembelajaran serta menuntut siswa lebih aktif mengembangkan pengetahuannya secara mandiri.

Modul merupakan salah satu bahan ajar yang dapat membantu siswa maupun guru dalam proses pembelajaran, karena dengan modul siswa dapat mengajar dirinya sendiri dan melakukan kontrol sendiri terhadap intensitas belajarnya (Asfiah dkk dalam Fadilah dkk, 2016). Rusel dalam Lusia dan Arief (2013) juga mengungkapkan bahwa pembelajaran modul akan menjadikan pembelajaran lebih efiesien, efektif, dan relevan.

Pengembangan modul pada penelitian ini dikombinasikan dengan model pembelajaran. Ada banyak model pembelajaran yang telah dikembangkan para ahli, namun yang menjadi dasar pemilihan model adalah yang sesuai dengan tuntutan kurikulum 2013 yang menuntut siswa lebih aktif dalam proses pembelajaran. Salah satu model pembelajaran yang memberikan kesempatan kepada siswa untuk aktif mengkonstruksi dan mengembangakan pengetahuan adalah model pembelajaran predict-observe-explain (POE). Kegiatan dalam POE meliputi memprediksi (predict), mengamati (observe), dan menerangkan (explain) dapat membentuk struktur kognitif siswa menjadi lebih baik, karena kegiatankegiatan dalam strategi ini memberikan kesempatan pada siswa untuk belajar secara konkret (Warsono \& Hariyanto dalam Rosdianto dkk 2017). Model pembelajaran POE memungkinkan siswa belajar proses (learning by process), sehingga memungkinkan tercapainya tujuan belajar baik kognitif, afektif (sikap), dan psikomotor (keterampilan) (Djumadi dan Santoso dalam Shofia dkk, 2017).

Penelitian pengembangan modul berbasis POE sudah dilakukan oleh Sari dan Alarifin (2016). Hasil penelitiannya adalah kualtias modul fisika berbasi POE menurut ahli materi, ahli media, dan ahli bahasa memiliki kriteria kelayakan sangat layak dengan presentase keidealan masing-masing sebesar 80,20\%, $80,30 \%$, dan $81,25 \%$ dan kefektivitas modul berbasis POE ditinjau dari kemampuan kognitif siswa mendapat kriteria tinggi. Penelitian mengenai pengembangan modul berbasis POE juga dilakukan oleh Nuraini dkk (2014), hasil 
menunjukkan bahwa modul berbasis POE disertai RD juga dapat menjadikan siswa lebih aktif selama pembelajaran karena kegiatan yang terdapat dalam modul mampu memfasilitasi siswa untuk mengembangkan aktifitas mental dan fisik secara optimal.

Berdasarkan hal-hal yang telah dikemukakan di atas, penulis tertarik untuk melakukan penelitian dengan judul "Pengembangan Modul Pembelajaran kimia Berbasis POE (Predict, Observe, Explain) Pada Materi Larutan Elektrolit dan Non Elektrolit"

\section{PROSEDUR PENELITIAN}

Jenis penelitian ini adalah penelitian dan pengembangan (research and development). Prosedur pengembangan dari penelitian ini mengadopsi model prosedural pengembangan Borg \& Gall. Berikut langkah-langkah pengembangan yang dilakukan peneliti adalah sebagai berikut: melakukan analisis kebutuhan, membuat perencanaan, mengembangkan produk, melakukan validasi, melakukan uji coba skala kecil, merevisi produk, melakukan uji coba skala menengah, melakukan revisi produk akhir.

Terdapat dua macam data penelitian yang diklasifikasikan berdasarkan sifatnya yaitu data kualitatif dan data kuantitatif. Data kualitatif berupa masukan, saran, komentar terhadap modul yang dikembangkan. Sedangkan data kuantitatif berupa data hasil lembar observasi yang diberikan pada validator ahli materi, ahli media/desain, dan guru bidang studi. Data kuantitatif juga didapatkan dari hasil angket uji coba modul pada skala kecil dan skala menengah.

Jenis instrumen yang digunakan untuk memperoleh data yang sesuai dengan permasalahan adalah sebagai berikut:

a. Pedoman Wawancara

Wawancara dilakukan untuk mendapatkan data kualitatif. Jenis wawancara pada penelitian ini yaitu wawancara semi terstruktur, dimana dalam pelaksanaanya lebih bebas bila dibandingkan dengan wawancara terstruktur. Wawancara dilakukan pada validator ahli materi, ahli media/desain guru bidang studi dan subyek uji coba untuk memperoleh tanggapan terhadap modul yang dikembangkan.

b. Lembar Validasi

Lembar validasi digunakan untuk memvalidasi modul hasil pengembangan. Lembar validasi ini diberikan kepada para validator ahli materi, validator ahli desain/media dan praktisi pendidikan/guru bidang studi. Ahli materi dan praktisi pendidikan/guru bidang studi memberikan penilaian terhadap aspek kelayakan isi, aspek kelayakan penyajian, dan aspek kelayakan bahasa. Validator ahli media/desain memberikan penilaian terhadap ukuran modul, desain sampul modul (cover), desain isi modul.

c. Angket Responden Siswa

Angket digunakan untuk mendapatkan data kualilatif dan kuantitatif. Angket ini diberikan pada siswa untuk mengetahui bagaimana respon siswa terhadap modul yang dikembangkan. Siswa diminta memberikan penilaian terhadap aspek tampilan, aspek penyajian materi dan aspek bahasa. 
Teknik analisa data dalam penelitian ini dilakukan dengan menggunakan analisa kualitatif dan analisa kuantitatif.

\section{Analisis kualitatif}

Analisis kualitatif pada penelitian ini adalah analisis yang digunakan untuk menganalisis data kualitatif seperti masukan dan saran dari validator ahli materi, ahli media/desain dan subjek uji coba.

2. Analisis kuantitatif

Analisis kuantitatif digunakan untuk mengkaji data lembar validasi diisi oleh validator ahli materi, validator ahli media/desain, praktisi pendidikan/guru bidang studi.

Validator ahli materi, validator ahli media/desain dan praktisi pendidikan/guru bidang studi lembar mengisi lembar validasi berdasarkan kriteria penilaian seperti pada Tabel 1 .

Tabel 1. Kriteria Penilaian Butir Lembar Validasi

\begin{tabular}{ccc}
\hline No & Kategori & Skor \\
\hline 1 & Sangat Baik & 4 \\
\hline 2 & Baik & 3 \\
\hline 3 & Kurang & 2 \\
\hline 4 & Sangat Kurang & 1 \\
\hline
\end{tabular}

(Noviani, 2014)

Data dianalisis menggunakan rumus sebagai berikut:

$$
P=\frac{\sum x}{\sum x i} \times 100 \%
$$

Keterangan:

(Hanafi, 2017)

$$
\begin{array}{ll}
\mathrm{P} & =\text { Persentase yang dicari } \\
\sum x & =\text { jumlah skor total validator } \\
\sum x i & =\text { jumlah skor total maksimal }
\end{array}
$$

Untuk memberikan makna dan pengambilan keputusan dari skor hasil perhitungan yang telah didapatkan diatas, skor dapat ditafsirkan dengan rentang seperti pada Tabel 2.

Tabel 2. Kriteria Kevalidan Berdasarkan Skala Likert

\begin{tabular}{cc}
\hline Presentase & Kriteria \\
\hline $85-100 \%$ & Sangat Valid \\
$69-84 \%$ & Valid \\
$53-68 \%$ & Cukup Valid \\
$37-52 \%$ & Kurang Valid \\
$21-36 \%$ & Sangat Tidak Valid \\
\hline
\end{tabular}


Berdasarkan kriteria pada Tabel 2 modul dalam penelitian pengembangan ini dikatakan memenuhi kriteria kualitas apabila hasil presentase > $68 \%$

Subjek uji coba melakukan pengisian angket berdasarkan kriteria penilaian seperti Tabel 3 di bawah ini.

Tabel 3. Kriteria Penilaian Butir Angket Responden Siswa

\begin{tabular}{ccc}
\hline No & Kategori & Skor \\
\hline 1 & Sangat Setuju & 4 \\
\hline 2 & Setuju & 3 \\
\hline 3 & Kurang Setuju & 2 \\
\hline 4 & Tidak setuju & 1 \\
\hline & & (Noviani, 2014)
\end{tabular}

Analisis kuantitatif digunakan untuk mengkaji data angket pada subjek uji coba skala kecil dan menengah, data dianalisis menggunakan rumus sebagai berikut:

$$
P=\frac{\sum x}{\sum x i} \times 100 \%
$$

(Hanafi, 2017)

Keterangan:

$$
\begin{array}{ll}
\mathrm{P} & =\text { Persentase yang dicari } \\
\sum x & =\text { jumlah skor total responden } \\
\sum x i & =\text { jumlah skor total maksimal }
\end{array}
$$

Untuk memberikan makna dan pengambilan keputusan dari skor hasil perhitungan yang telah didapatkan diatas, skor dapat ditafsirkan dengan rentang seperti pada Tabel 4 dibawah ini.

Tabel 4. Kriteria Skor Angket Respon Siswa

\begin{tabular}{cc}
\hline Presentase & Kriteria \\
\hline $85-100 \%$ & Sangat Baik \\
$70-84 \%$ & Baik \\
$55-69 \%$ & Cukup \\
$40-54 \%$ & Kurang \\
$0-39 \%$ & Sangat Kurang \\
\hline
\end{tabular}

(Utomo dalam Izzah, 2017)

\section{HASIL DAN PEMBASAN}

\section{Hasil Penelitian}

a. Deskripsi Produk

Hasil pengembangan ini menghasilkan produk berupa modul pembelajaran kimia berbasis POE (predict, observe, explain) pada materi larutan elektrolit dan non elektrolit. Berikut identitias produk: 
1) Bentuk file

2) Judul

3) Materi

4) Sasaran

5) Nama Penyususun

6) Halaman

7) Ukuran Kertas
: Bahan cetak (material printed)

: Modul Pembelajaran Kimia Berbasis

POE (Predict, Observe,

Explain) pada Materi Larutan

Elektrolit dan Non Elektrolit

: Larutan Elektrolit dan Non Elektrolit

: Siswa SMA/MA kelas X

Etrie Jayanti, M.Pd

: 18 Halaman

: $\mathrm{A} 4$

Berikut rincian bagian-bagian modul yang dikembangkan:

1) Pendahuluan

Pada bagian pendahuluan berisi antara lain: (1) kata pengantar, (2) daftar isi, (3) petunjuk pengunaan praktikum , (4) kompetensi dasar dan kompetensi inti, (5) peta konsep.

2) Pembelajaran

Pada bagian ini berisi materi larutan elektrolit dan non elektrolit. Adapun penyampaian materi dalam isi modul dikemas sesuai dengan tahapan modul pembelajaran $P O E$ (predict, observe, explain).

1. Tahap pertama yaitu predict atau prediksi, pada tahap ini peseta didik diberikan masalah atau sistuasi kemudian siswa dituntut untuk membuat prediksi terhadap masalah atau situasi yang diberikan tersebut.

2. Tahap kedua yaitu observe atau mengamati, pada tahap ini siswa akan melakukan suatu pengamatan untuk membuktikan prediksi yang telah mereka buat.

3. Tahap ketiga yaitu explain atau menjelaskan, pada tahap ini siswa menjelaskan hasil pengamatan yang telah dilakukan serta dikaitkan dengan prediksi yang telah dibuat sebelumnya.

3) Evaluasi

Bagian evaluasi berisi soal latihan terkait materi larutan elektrolit dan non elektrolit. Soal berbentuk pilihan ganda, terdiri dari 10 soal. Soal ini juga dilengkapi dengan kunci jawaban yang berguna bagi siswa untuk mengecek kebenaran jawaban dari soal yang telah siswa kerjakan.

4) Penutup

Pada bagian ini memuat refensi yang menjadi rujukan peneliti dalam mengembangkan modul pembelajaran berbasis $P O E$ (predict, observe, explain) pada materi larutan elektrolit dan non elektrolit.

\section{b. Hasil Validasi}

1) Hasil Validasi Ahli Materi

a) Pemaparan Data Kuantitatif

Hasil Validasi ahli materi pada seluruh aspek kriteria dapat dilihat pada 
Tabel 5.

Tabel 5.Hasil Validasi Ahli Materi Pada Seluruh Aspek Kriteria

\begin{tabular}{lcccc}
\hline \multicolumn{1}{c}{ Kriteria } & $\sum \mathbf{x}$ & $\sum \mathbf{x i}$ & $\mathbf{P}$ & $\begin{array}{c}\text { Kriteria } \\
\text { Valid }\end{array}$ \\
\hline Aspek Kelayakan Isi & 48 & 39 & 81,3 & Valid \\
\hline $\begin{array}{l}\text { Aspek Kelayakan } \\
\text { Penyajian }\end{array}$ & 48 & 41 & 85,4 & $\begin{array}{c}\text { Sangat } \\
\text { Valid }\end{array}$ \\
\hline $\begin{array}{l}\text { Aspek kelayakan bahasa } \\
\text { Jumlah }\end{array}$ & 48 & 40 & 83,3 & Valid \\
\hline
\end{tabular}

Dari Tabel 5 dapat disimpulkan bahwa ahli materi memberikan penilaian terhadap modul pembelajaran berbasis POE (predict, observe, explain) pada materi larutan elektrolit dan non elektrolit mencapai 83,3\% dan berdasarkan kriteria dinyatakan bahwa modul pembelajaran ini valid.

b) Pemaparan Data Kualitatif

Adapun data kualitatif hasil validasi ahli materi yaitu berupa masukan dan saran dalam pernyataan terbuka, antara lain sebagai berikut:

1. Lengkapi modul dengan $\mathrm{KI}$ dan $\mathrm{KD}$.

2. Peta konsep belum terlihat.

3. Pada kegiatan observe yang pertama, tambahkan berat/volume pada bahan yang digunakan dalam aktivitas praktikum.

4. Pada kegiatan observe yang pertama bagian prosedur percobaan, sebaiknya diberi penjelasan berapa volume air pada setiap beaker gelas.

5. Pada kegiatan observe yang pertama bagian kolom hasil pengamatan. Opsi gelembung gas yang mulanya "ada dan tidak ada", sebaiknya diganti dengan opsi "banyak, sedikit, tidak ada". Hal ini berguna untuk mellihat perbedaan banyaknya gelembung gas dari "air murni + garam" dengan "air murni + cuka".

6. Pada kegiatan observe yang kedua, sebaiknya diberi keterangan terhadap gambar tersebut, serta beri keterangan dari lambang-lambang yang termuat dalam gambar.

7. Pada kegiatan explain mengenai reaksi ioniasi, ada beberapa hal yang perlu diperbaiki:

a. Persamaan reaksi yang dibuat keliru.

b. Pada latihan menuliskan reaksi ionisasi sebaiknya jangan gunakan $\mathrm{NaOH}$ lagi, karena $\mathrm{NaOH}$ sudah ada dalam contoh.

c. Pada kegiatan explain yang memuat kolom senyawa ion dan kovalen non polar, tambahkan satu kolom yang memuat data daya hantar listriknya.

8. Terdapat beberapa kalimat yang salah dalam pengetikan.

9. Ada beberapa pola kalimat yang harus diperbaiki.

10. Pada bagian evaluasi ada beberapa kalimat soal perlu diperbaiki dan diganti. 
2) Hasil Validasi Ahli Desain

a) Pemaparan Data Kuantitatif

Hasil validasi dari ahli media/desain pada seluruh komponen dapat dilihat pada Tabel 6.

Tabel 6. Hasil Validasi Ahli Media/Desain pada Seluruh Aspek Kriteria

\begin{tabular}{lrrrl}
\multicolumn{1}{c}{ Komponen } & $\sum \mathbf{x}$ & \multicolumn{1}{c}{$\sum \mathbf{x i}$} & \multicolumn{1}{c}{$\mathbf{P}$} & \multicolumn{1}{c}{ Kriteria Valid } \\
\hline Ukuran Modul & 8 & 7 & 87,5 & Sangat Valid \\
\hline $\begin{array}{l}\text { Desain Sampul } \\
\text { Modul (cover) }\end{array}$ & 36 & 34 & 94,4 & Sangat Valid \\
\hline Desain Isi Modul & 100 & 99 & 99 & Sangat Valid \\
\hline Jumlah & 144 & 140 & 97,2 & Sangat Valid \\
\hline
\end{tabular}

Dari Tabel 6 dapat disimpulkan bahwa ahli media/desain memberikan penilaian terhadap modul pembelajaran kimia berbasis $P O E$ (predict, observe, explain) pada materi larutan elektrolit dan non elektrolit mencapai 97,2\% dan berdasarkan kriteria dinyatakan bahwa modul pembelajaran ini sangat valid.

b) Pemaparan Data Kualitatif

Adapun data kualitatif hasil validasi ahli desain yaitu berupa masukan dan saran untuk perbaikan modul pembelajaran kimia berbasis POE (predict, observe, explain). Ahli desain menyarankan untuk print out kualitas gambar ditingkatkan.

3) Hasil Validasi Praktisi/Guru Bidang Studi

a) Pemaparan Data Kuantitatif

Hasil validasi dari praktisi/guru bidang studi pada seluruh aspek kriteria dapat dilihat pada Tabel 7.

Tabel 7. Hasil Validasi Praktisi/Guru Bidang Studi pada Seluruh Aspek Kriteria

\begin{tabular}{|l|c|c|c|c|}
\hline \multicolumn{1}{|c|}{ Kriteria } & $\sum \mathbf{x}$ & $\sum \mathbf{x i}$ & $\mathbf{P}$ & Kriteria Valid \\
\hline Aspek Kelayakan Isi & 48 & 41 & 85,4 & Sangat Valid \\
\hline Aspek Kelayakan Penyajian & 48 & 43 & 89,6 & Sangat Valid \\
\hline Aspek Kelayakan Bahasa & 48 & 41 & 85,4 & Sangat Valid \\
\hline Jumlah & 144 & 125 & 86,8 & Sangat Valid \\
\hline
\end{tabular}

Dari Tabel 7 dapat disimpulkan bahwa praktisi/guru bidang studi memberikan penilaian terhadap modul pembelajaran kimia berbasis POE (predict, observe, explain) pada materi larutan elektrolit dan non elektrolit mencapai $88,8 \%$ dan berdasarkan kriteria dinyatakan bahwa modul pembelajaran ini sangat valid. 
b) Pemaparan Data Kualitatif

Adapun data kualitatif hasil validasi praktisi/guru bidang studi yaitu berupa masukan dan saran dalam pernyataan terbuka antara lain sebagai berikut:

1. Pada kegiatan observe yang pertama bagian alat dan bahan, tambahkan bahan berupa tissue atau kain lap.

2. Pada kegiatan observe yang pertama bagian prosedur percobaan, perbaiki kalimat pada nomor 3.

3. Ada beberapa kesalahan pengetikan.

c. Hasil Uji Coba

Uji coba dilakukan sebanyak dua kali yaitu uji coba skala kecil dan uji coba skala menengah.

1. Uji Coba Skala Kecil

Secara keseluruhan data hasil uji coba pada skala kecil dapat dilihat pada Tabel 8 dibawah ini.

Tabel 8. Data Hasil Uji Keseluruah pada Uji Coba Skala Kecil

\begin{tabular}{lcccc}
\hline \multicolumn{1}{c}{ Pernyataan } & $\sum \mathbf{x}$ & $\sum \mathbf{x i}$ & $\mathbf{P}$ & Kategori \\
\hline Aspek Tampilan & 120 & 98 & 81,7 & Baik \\
\hline Aspek Penyajian Materi & 168 & 136 & 81,0 & Baik \\
\hline Aspek Bahasa & 96 & 69 & 71,9 & Baik \\
\hline Jumlah & 384 & 303 & 78,9 & Baik \\
\hline
\end{tabular}

Dari Tabel 8 dapat diketahui bahwa respon siswa pada uji skala kecil terhadap modul pembelajaran kimia berbasis POE (predict, observe, explain) dikategorikan baik.

Pada uji skala kecil ini, siswa menyarakan untuk lebih teliti dalam penulisan, karena terdapat beberapa bagian yang salah dalam pengetikan. Berikut gambar contoh komentar dan masukan dari siswa.

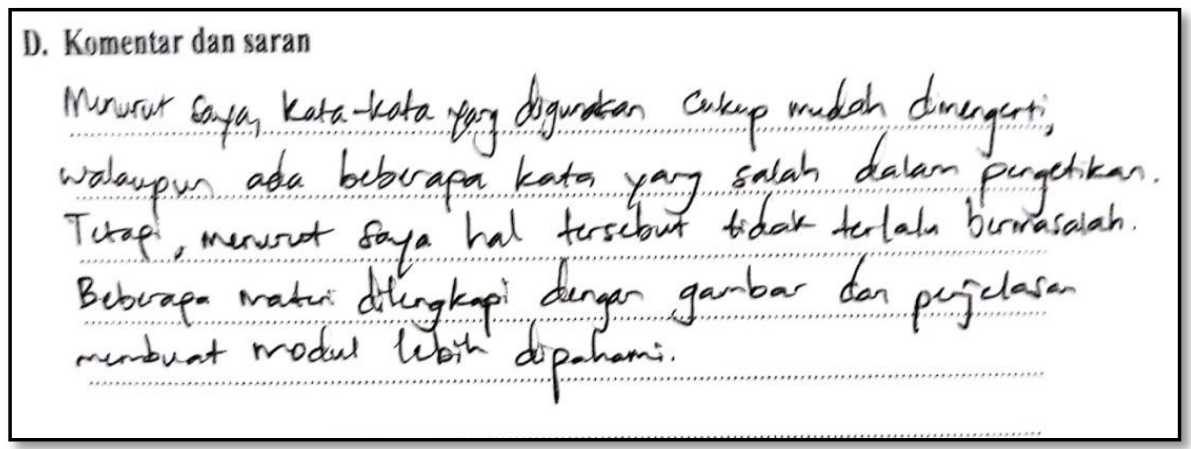

Gambar 1. Contoh Komentar dan Saran dari Siswa

2). Uji Coba Skala Menengah

Secara keseluruhan data hasil uji coba pada skala menengah dapat dilihat pada Tabel 9 dibawah ini. 
Tabel 9. Data Hasil Uji Keseluruah pada Uji Coba Skala Menengah

\begin{tabular}{lcccc}
\hline \multicolumn{1}{c}{ Pernyataan } & $\sum \mathbf{x}$ & $\sum \mathbf{x i}$ & $\mathbf{P}$ & Kategori \\
\hline Aspek Tampilan & 600 & 500 & 83,3 & Baik \\
\hline $\begin{array}{l}\text { Aspek Penyajian } \\
\text { Materi }\end{array}$ & 840 & 686 & 81,7 & Baik \\
\hline Aspek Bahasa & 480 & 389 & 81,0 & Baik \\
\hline \multicolumn{1}{c}{ Jumlah } & 1920 & 1575 & 82,0 & Baik \\
\hline
\end{tabular}

Dari Tabel 9 dapat diketahui bahwa respon siswa pada uji skala menengah terhadap modul pembelajaran kimia berbasis $P O E$ (predict, observe, explain) pada materi larutan elektrolit dan non elektrolit dikategorikan baik.

\section{KESIMPULAN DAN SARAN}

\section{Kesimpulan}

1. Hasil validasi modul pembelajaran kimia berbasis POE (predict, observe, explain) pada materi larutan elektrolit dan non elektrolit dari ahli materi memperoleh persentase nilai sebesar 83,3\% dengan kategori valid, dari ahli desain/media memperoleh persentase nilai sebesar 97,2\% dengan kategori sangat valid, dan dari praktisi pendidikan/guru bidang studi memperoleh persentase nilai sebesar $88,8 \%$ dengan kategori sangat valid. Rata-rata persentase nilai dari tiga validator mencapai $89,9 \%$ dan dinyatakan pada kategori sangat valid.

2. Respon siswa terhadap modul pembelajaran kimia berbasis POE (predict, observe, explain) pada materi larutan elektrolit dan non elektrolit dapat dikategorikan baik dimana pada uji skala kecil memperoleh persentase nilai sebesar 78,9\% dan dinyatakan dalam kategori baik, pada uji skala menengah memperoleh persentase nilai sebesesar $82,0 \%$ dan dinyatakan dalam kategori baik.

\section{Saran}

1. Tahap pengembangan modul pembelajaran kimia berbasis POE (predict, observe, explain) pada materi larutan elektrolit dan non elektrolit hanya sampai pada tahap melakukan revisi setelah dilakukan uji coba skala menengah. Peneliti menyarankan bagi pembaca yang tertarik terhadap penelitian ini untuk melanjutkan penelitian sampai ke tahap desiminasi dan implementasi produk.

2. Sesuai dengan hasil penelitian, bahwa modul pembelajaran kimia berbasis $P O E$ (predict, observe, expalin) pada materi larutan elektrolit dan non elektrolit sangat valid dan layak digunakan, sehingga disarankan bagi guru bidang studi pada mata pelajaran kimia dapat mengunakan modul pembelajaran ini.

\section{DAFTAR PUSTAKA}

Fadilah, R. N., Yahya, F., Rahman, A.H. (2016). Pengembangan Modul Fisika Beorientasi Pada Model Motivasi ARCS (Attention, Relevance, Confidence, Satisfaction) Pokok Bahasan Suhu dan Kalor Siswa Kelas X SMA. Prosising Seminar Nasional Pendidikan. Universitas Samawa. 
Hanafi, I. (2017). Pengembangan Modul Geografi Berbasis Integrasi SainsAgama pada Siswa Kelas XI Madrasah Aliya Negeri 1 Malang. Skripsi. Universitas Islam Negeri Maulana Malik Ibrahim Malang.

Izzah, I. N. (2017). Pengembangan Media Pembelajaran Touch And Play 3D Images Berbasis Adobe Flash Materi PancaIndera Kelas IV Sekolah Dasar. Skripsi. Universitas Muhammadiyah Malang.

Lusia, M. T. A., Arief, A. (2013). Pengembangan Modul Fisika Berorientasi Learning Cycle 5E pada Materi Gerak Kelas VII SMP. Jurnal Inovasi Pendidikan Fisika, 2 (3), 147-151.

Medina, P. (2015). Analisis Miskonsepsi Siswa Kelas X Pada Materi Larutan Elektrolit dan Non elektrolit Serta Reaksi Oksidasi Dan Reduksi Dalam Pembelajaran Kimia Di SMAN Kota Padang. Jurnal Pendidikan dan Teknologi Informasi, 2 (1), 1-9.

Noviani, N. (2014). Pengembangan Modul Segi Empat Dengan Pendekatan Problem Solving Untuk Siswa SMP Kelas VII. Skripsi. Universitas Negeri Yokyakarta.

Nuraini, N., Karyanto, P ., Sudarisman, S. (2014). Pengembangan Modul Berbasis POE (Predict, Observe, and Explain) Disertai Roundhouse Diagram untuk Memberdayakan Keterampilan Proses Sains dan Kemampuan Menjelaskan Siswa Kelas X SMA Negeri 5 Surakarta (Penelitian dan Pengembangan Materi Pencemaran Lingkungan Tahun Pelajaran 2013/2014). Bioedukasi, 7 (1), 37-43.

Paparan Wakil Menteri Pendidikan dan Kebudayaan Republik Indonesia Bidang Pendidikan. (2014). Konsep dan Kurikulum 2013. Jakarta: Kementerian Pendidikan dan Kebudayaan.

Rosdianto, H., Murdani, E., Hendra. (2017). Implementasi Model Pembelajaran POE (Predict Observe, Explain) Untuk Meningkatkan Pemahaman Konsep Siswa Pada Materi Hukum Newton. Jurnal Pendidikan Fisika, 6 (1), 55-57.

Sari, A. T. W., Alarifin, D. H. (2016). Pengembangan Modul Berbasis POE (Predict, Observe, Explain) Materi Usaha dan Energi Ditinjau Dari Kemampuan Kognitif. JPF Jurnal Pendidikan Fisika, 4 (2), 124-136.

Shofia, R. I., Bektiarso, S., Supriadi, D. (2017). Penerapan Model POE (PredictObserve-Explain) dengan Metode Eksperimen Terhadap Hasil Belajar IPA dan Retensi Siswa Di SMP. Jurnal Pembelajaran Fisika, 6 (4), 356-363.

Wulandaru, N. A. (2015). Analisis Pemahaman Konseptual Materi Larutan Elektrolit dan Non Elektrolit Siswa Kelas X IPA SMAN 9 Malang. Skripsi. Jurusan Kimia Fakultas MIPA Universitas Malang. 